\title{
PENINGKATAN KOMPETENSI MENGEMBANGKAN TES BERPERSPEKTIF HIGHER ORDER OF THINKING SKILLS (HOTS) PADA GURU BAHASA INDONESIA SMP
}

\author{
Sarwiji Suwandi, Memet Sudaryanto, Nugraheni Eko Wardani, \\ Sugit Zulianto, Chafit Ulya, Titi Setiyoningsih \\ Universitas Sebelas Maret \\ Email: sarwijiswan@staff.uns.ac.id, memetsudaryanto@staf..uns.ac.id, \\ nugraheniekowardani_99@staff.uns.ac.id,sugit_zulian@staff.uns.ac.id, \\ chafit@staff.uns.ac.id, setiyoningsih.2812@staff.uns.ac.id
}

\begin{abstract}
Abstrak: Pembelajaran Bahasa Indonesia berorientasi pada keterampilan berpikir tingkat tinggi atau Higher Order Thinking Skill (HOTS). Namun demikian, berdasarkan observasi terbatas teridentifikasi soal-soal buatan guru belum sepenuhnya berorientasi pada pengembangan keterampilan berpikir tingkat tinggi. Penelitian ini merupakan penelitian deskriptif kualitatif dengan pendekatan studi kasus. Sumber data meliputi guru-guru Bahasa Indonesia di SMPN 4 Surakarta dan tugas tertulis. Teknik pengumpulan data dengan wawancara terstruktur dan tidak terstruktur serta analisis dokumen. Teknik validitas data melalui triangulasi metode dengan cara mencocokkan data antara wawancara dan hasil tes tertulis. Teknik analisis data dengan analisis model interaktif. Setelah dilakukan tindakan perbaikan (treatment) kemampuan guru dalam mengembangkan soal Bahasa Indonesia mengalami perubahan terutama dalam menentukan kata kerja operasional yang dibutuhkan terukur sesuai dengan dimensi tesnya. Ide pengembangan instrumen tes yang dikembangkan oleh guru bisa bercabang dan divergen sesuai dengan tujuan tes yang hendak dicapai. Hal ini menunjukkan bahwa upaya tindakan perbaikan (treatment) dapat meningkatkan kemampuan guru Bahasa Indonesia dalam menyusun soal berprespektif HOTS. Indikator menunjukkan kemampuan terukur sebagai alat untuk mencapai tujuan. Pengguna potensial hasil penelitian ini adalah sekolah dan Dinas Pendidikan Kota Surakarta dalam mengembangkan kompetensi profesional pendidik.
\end{abstract}

Kata Kunci: peningkatan kompetensi, penyusunan, soal Bahasa Indonesia, HOTS.

\section{INCREASING THE COMPETENCY OF THE TEST DEVELOPMENT BASED HIGHER ORDER THINKING SKILLS (HOTS) OF JUNIOR HIGH SCHOOL INDONESIAN LANGUAGES TEACHERS}

\begin{abstract}
Indonesian language learning is oriented towards higher order thinking skills. However, based on limited observations it was identified that the teacher-made questions were not fully oriented towards developing higher order thinking skills. This research is a qualitative descriptive study with a case study approach. Data sources include Indonesian language teachers at SMPN 4 Surakarta and written assignments. Data collection techniques with structured and unstructured interviews and
\end{abstract}

BASASTRA Jurnal Bahasa, Sastra, dan Pengajarannya

Volume 9 Nomor 1, April 2021, P-ISSN 2302-6405, E-ISSN 2714-9765 
document analysis. Technique of data validity through triangulation of methods by matching data between interviews and written test results. Data analysis techniques with interactive model analysis. After taking corrective action (treatment), the teacher's ability to develop Indonesian language questions has changed, especially in determining the operational verb required to measure according to the dimensions of the test. The idea of developing a test instrument developed by the teacher can be branched and divergent according to the test objectives to be achieved. This shows that the remedial action (treatment) can improve the ability of Indonesian language teachers to compile questions with a HOTS perspective. Indicators show measurable ability as a means to achieve goals. Potential users of the results of this study are schools and the Surakarta City Education Office in developing professional competence of educators.

Keywords: competency improvement, preparation, Indonesian language questions, HOTS.

PENDAHULUAN

Guru merupakan seorang fasilitator dalam kegiatan pembelajaran di sekolah. Sebagai fasilitator, guru memiliki peran strategis dalam meningkatkan mutu pembelajaran. Seorang guru yang memiliki kompetensi tentu akan menghasilkan siswa yang berkualitas. Hal tersebut sejalan dengan amanat Undang-Undang Republik Indonesia Nomor 20 Tahun 2003 tentang Sistem Pendidikan Nasional di Pasal 3 yakni, "Pendidikan Nasional berfungsi mengembangkan kemampuan dan membentuk watak serta peradaban bangsa yang bermartabat dalam rangka mencerdaskan kehidupan bangsa, bertujuan untuk berkembangnya potensi peserta didik agar menjadi manusia yang beriman dan bertakwa kepada Tuhan Yang Maha Esa, berakhlak mulia, sehat, berilmu, cakap kreatif, mandiri, serta menjadiw warga negara yang demokratis serta beranggung jawab."

Kementerian Pendidikan dan Kebudayaan (Kemdikbud) tepatnya pada tanggal $6 \quad$ Desember 2016 mengungkapkan hasil nilai Programme for International Student Assessment (PISA). Perlu diketahui bahwa PISA adalah sistem ujian berdasarkan inisiasi dari Organisation for Economic Cooperation and Development (OECD) bertujuan melaukan evaluasi sistem pendidikan terhadap 72 negara seluruh dunia. Pelaksanaan PISA yakni setiap tiga tahun, siswa dengan usia kisaran 15 tahun dipilih dengan acak untuk kemudian ikut serta tes dari tiga kompetensi dasar. Kompetensi dasar yang dimaksud yaitu membaca, matematika, dan sains.

Tidak hanya pengetahuan berupa kompetensi dasar, PISA juga mengukur kemampuan siswa dalam mengaplikasikan pengetahuan dasar tersebut. Berdasarkan hasil survei yang dilakukan tahun 2015 terungkap pencapaian pendidikan di Indonesia mengalami kenaikan yaitu sebesar 22,1 poin. Perlu diketahui, seperti yang sudah dijelaskan sebelumnya bahwa soal-soal

BASASTRA Jurnal Bahasa, Sastra, dan Pengajarannya

Volume 9 Nomor 1, April 2021, P-ISSN 2302-6405, 2E-ISSN 2714-9765 
yang diujikan pada PISA tidak hanya mengukur kemampuan dalam penerapan konsep saja, tetapi justru terkait cara menerapkan konsep tersebut agar dapat diterapkan dalam berbagai situasi (Kurniati, dkk., 2016).

Hasil uji PISA pada tahun 2015 menunjukkan peningkatan yang siginifikan terlihat pada kompetensi sains, yakni dari 382 poin di tahun 2012 menjadi 403 poin di tahun 2015. Kemudian untuk kompetensi matematika mengalami peningkatan dari 375 poin di tahun 2012 naik menjadi 386 poin pada tahun 2015. Namun kompetensi membaca tampak belum mengalami peningkatan yang berarti, dari 396 di tahun 2012 menjadi 397 poin pada tahun 2015. Kenaikan yang sudah disebutkan menjadikan posisi Indonesia naik 6 peringkat jika dibandingkan posisi peringkat kedua dari bawah di tahun 2012

(kemdikbud.go.id/main/blog/2016/).

Meskipun pada kompetensi membaca khususnya belum menampilkan hasil yang memuaskan, setidaknya kenaikan tersebut dapat memberikan semangat, harapan, serta upaya peningkatan mutu pendidikan. Terkait komitmen dan ikhtiar dalam peningkatan mutu pendidikan Indonesia jangan sampai berkurang. Oleh sebab itu, guru-dalam hal ini guru bahasa Indonesia-sebagai ujung tombak dalam sistem pendidikan tak henti harus terus meningkatkan kompetensinya supaya dapat mengimplementasikan kurikulum dengan tepat dan baik.

Berdasarkan materi dalam peningkatan kompetensi profesi guru, dalam hal ini terdapat delapan materi guna meningkatkan kompetensi guru yaitu: 1) pelaksanaan kurikulum 2013;2) penyusunan perangkat pembelajaran seperti silabus dan RPP (Rencana Pelaksanaan Pembelajaran); 3) penilaian; 4) media pembelajaran inovatif; 5) karya tulis ilmiah seperti menulis di media massa, jurnal, maupun buku; 6) penelitian tindakan kelas (PTK), 7) penyusunan soal tingkat tinggi (High Order Thinking Skills-HOTS), 8) dan metodologi pembelajar (Kastawi \& Yuliejantiningsih, 2019).

Salah satu tantangan yang dihadapi guru adalah pelaksanaan pembelajaran bahasa dan sastra Indonesia untuk mengasah dan mengembangkan keterampilan berpikir tingkat tinggi atau higher order thinking skill (HOTS). Tantangan tersebut akan dapat dijawab dengan baik apabila seorang guru memiliki pemahaman yang baik terkait konsep keterampilan berpikir tingkat tinggi, kemudian juga dapat memahami karakteristik siswa, selain itu mampu menerapkan dengan baik pendekatan saintifik dan model-model pembelajaran yang bersesuaian serta menerapkan penilaian autentik dalam pembelajaran. Mengikuti perkembangan zaman, 
menurut Sudaryanto, dkk. (2019) penilaian kemampuan berbahasa saat ini menuntut peserta tes menguasai aspek kebahasaan secara menyeluruh tanpa memahami konteks yang digunakan dalam kehidupan sehari-hari. Model penilaian yang dibutuhkan adalah ukuran yang efektif, efisien, dan akurat dari dimensi yang diuji.

Berdasarkan observasi terbatas diketahui bahwa soal-soal yang disusun guru belum sepenuhnya berorientasi pada pengembangan keterampilan berpikir aras tinggi siswa. Berdasarkan fakta tersebut, upaya untuk meningkatkan kompetensi guru Bahasa Indonesia dalam menyusun soal berbasis keterampilan berpikir aras tinggi (HOTS) sangat diperlukan. Dengan kemampuan tersebut guru akan dapat melakukan penilaian pembelajaran sesuai dengan tuntututan Kurikulum 2013 dan pembelajaran akan menjadi lebih efektif. Hal tersebut sejalan dengan hasil penelitian Widodo \& Kadarwati (2013) yang diperoleh simpulan bahwa mengaplikasikan pembelajaran dengan perspektif Higher Order Thinking menjadikan aktivitas dan karakter siswa meningkat menjadi lebih baik, hingga bermuara pada meningkatnya hasil belajar siswa.

Menurut Resnick (1987), keterampilan berpikir tingkat tinggi merupakan proses berpikir kompleks dalam menguraikan materi, membuat simpulan, membangun representasi, menganalisis, dan membangun hubungan dengan melibatkan aktivitas mental yang paling dasar. Keterampilan ini juga mengacu pada proses tingkat tinggi dalam taksonomi Bloom. Berdasarkan pendapat Bloom terdapat dua bagian keterampilan yakni, 1) keterampilan tingkat rendah dalam proses pembelajaran, mencakup mengingat (remembering), memahami (understanding), menerapkan (applying) dan 2) keterampilan berpikir tingkat tinggi, mencakup keterampilan menganalisis (analysing), mengevaluasi (evaluating), dan mencipta (creating).

Melalui taksonomi yang direvisi, Anderson dan Krathwoll (2001) menjelaskan tentang proses yang menunjukkan kompleksitas kognitif dengan menambahkan dimensi pengetahuan, yang kemudian diklasifikasikan menjadi faktual, konseptual, prosedural, serta metakognitif. Di dalam pengetahuan faktual terdapat elemen-elemen dasar yang wajib diketahui oleh peserta didik jika mereka akan dikenalkan dengan suatu disiplin atau guna menyelesaikan berbagai masalah di dalamnya. Selanjutnya pengetahuan konseptual terdiri dari skema-skema, model-model mental, atau teori-teori eksplisit dan implisit dalam model-model psikologi kognitif yang berbeda. Lalu pengetahuan prosedural mengacu pada pengetahuan 
mengenai cara melakukan sesuatu. Serta pengetahuan metakognitif merupakan pengetahuan terkait kesadaran secara umum atau sama halnya dengan kewaspadaan dan pengetahuan tentang kesadaran diri seseorang.

Keempat dimensi pengetahuan tersebut akan berbeda pada tiap satuan pendidikan. Satuan pendidikan SD dan sederajat, siswa (lulusan) dituntut memiliki pengetahuan faktual, konseptual, prosedural, dan metakognitif pada tingkat dasar terkait ilmu pengetahuan, teknologi, seni, dan budaya. Siswa dapat mengaitkan pengetahuan di atas dalam konteks diri sendiri, keluarga, sekolah, masyarakat dan lingkungan alam sekitar, bangsa, dan negara. Untuk satuan pendidikan SMP, siswa harus memiliki pengetahuan faktual, konseptual, prosedural, dan metakognitif pada tingkat teknis dan spesifik sederhana terkait ilmu pengetahuan, teknologi, seni, dan budaya. Siswa dapat mengaitkan pengetahuan tersebut dalam konteks diri sendiri, keluarga, sekolah, masyarakat dan lingkungan alam sekitar, bangsa, negara, dan kawasan regional. Sementara itu, untuk satuan pendidikan SMA, siswa memiliki pengetahuan faktual, konseptual, prosedural, dan metakognitif pada tingkat teknis, spesifik, detail, dan kompleks terkait ilmu pengetahuan, teknologi, seni, budaya, dan humaniora.
Mereka diharapkan dapat mengaitkan pengetahuan tersebut dalam konteks diri sendiri, keluarga, sekolah, masyarakat dan lingkungan alam sekitar, bangsa, negara, serta kawasan regional dan internasional.

Menurut Afandi \& Sajidan (2017), keterampilan berpikir tingkat tinggi sebagai transfer of knowledge, critical and creative thinking, dan problem solving. Keterampilan berpikir tingkat tinggi berhubungan dengan keterampilan berpikir sesuai ranah kognitif, afektif, dan psikomotor yang terintegrasi pada proses pembelajaran. Pembahasan tentang berpikir tingkat tinggi memang erat kaitannya dengan berpikir kritis. Perlu diketahui bahwa berpikir kritis merupakan suatu proses aktif seseorang berpikir segala hal secara mendalam, mengajukan berbagai pertanyaan, juga secara aktif menemukan informasi yang relevan (Fisher, 2009).

Menurut Arends (2012) terdapat enam unsur dasar tahapan berpikir kritis yaitu: (1) focus (identifikasi masalah secara baik); (2) reason (alasan-alasan yang diberikan logis atau tidak disimpulkan seperti dalam permasalahan yang telah ditentukan); (3) inference (jika alasan yang dikembangkan tepat, maka alasan tersebut harus sampai pada kesimpulan yang sebenarnya); (4) situation (membandingkan dengan situasi yang ada); (5) clarity (harus ada 
kejelasan istilah maupun penjelasan yang digunakan pada pendapat sehingga tidak ada kesalahan pengambilan sesimpulan); dan (6) overview (pengecekan terhadap temuan, putusan, perhatian, yang dipelajari, dan disimpulkan).

Wardani, dkk. (2020) dalam penelitiannya menunjukkan bahwa meskipun guru memahami terkait HOTS, namun dalam praktiknya mereka cenderung kurang konsisten. Berdasarkan pemaparan tersebut maka perlu dilakukan penelitian terkait upaya peningkatan yang dilakukan yakni dengan tindakan perbaikan (treatment) pemahaman dan keterampilan membuat soal berperspektif HOTS terhadap guru Bahasa Indonesia di SMP Negeri Surakarta. Sehingga tujuan dari penelitian ini mendeskripsikan dan menjelaskan peningkatan kompetensi menyusun soal berperspektif Higher Order Thinking Skills (HOTS) guru Bahasa Indonesia SMP Negeri Kota Surakarta.

\section{METODE}

Penelitian ini merupakan penelitian deskriptif kualitatif dengan teknik studi kasus. Sumber data merupakan guru-guru Bahasa Indonesia di SMPN 4 Surakarta dan lembar jawab tugas tertulis. Tes tertulis diberikan kepada guru untuk mengetahui pemahaman guru mengenai kemampuan berpikir aras tinggi.
Teknik pengumpulan data dengan wawancara informan secara terstruktur dan tidak terstruktur serta analisis tugas tertulis. Teknik validitas data melalui triangulasi sumber data dengan cara mencocokkan data antara wawancara informan dan hasil tes tertulis. Teknik analisis data dengan analisis model interaktif Miles \& Huberman (dalam Sutopo, 2002) melalui langkah reduksi data, penyajian data, dan penarikan ke simpulan.

\section{HASIL DAN PEMBAHASAN}

Sekolah yang dipilih menjadi mitra Program Pengabdian kepada Masyarakat yaitu SMP Negeri 4 Surakarta. Berikut dipaparkan profil singkat sekolah tersebut, khususnya guru bahasa Indonesia dan siswa yang menjadi subjek dalam pegiatan pengabdian ini. SMPN 4 Kota Surakarta mendapat kepercayaan dari Kementrian Pendidikan dan Kebudayaan menjadi Sekolah Rujukan 2018. Hal itu diungkap Kepala SMP Negeri 4 kota Surakarta Sri Wuryanti, S.Pd., M.Pd. Dikatakan, pihaknya telah melaksanakan Sistem Penjaminan Mutu Internal dengan menerapkan 8 standar kompetensi ditambah Program Budaya dan Lingkungan. Untuk itu, pihaknya mengembangkan Laboratorium Inovasi Prebawa sebagai akronim dari Prestasi dan Berbudaya Jawa sehingga pengembangan inovasi difokuskan pada pendidikan karakter. 
Program penguatan pendidikan karakter dan literasi juga dilakukan dengan pengadaan Pojok Baca pada kelas 7 serta adanya ornamen Jawa pada ruang kelas. Sri Wuryanti menyatakan pihaknya ke depan akan menjadikan SMP Negeri 4 sebagai Sekolah Budaya dan Rumah Kreasi Seni, sebagai bagian pendidikan karakter, seiring dengan program pengembangan pusat unggulan akademik dan nonakademik yang telah dicapai selama ini, juga Program Sekolah Adiwiyata sebagai bagian pengembangan ekosistem.

SMP Negeri 4 Surakarta saat ini memiliki 5 orang guru bahasa Indonesia yang mengampu 855 orang siswa yang terbagi dalam 27 rombel. Kepala SMPN 4 Surakarta juga sebagai guru bahasa Indonesia yang sarat prestasi, yang antara lain sebagai Kepala Sekolah Berprestasi Tingkat Jawa Tengah. Berdasarkan wawancara dengan sejumlah guru, pelaksanaan pembelajaran Bahasa Indonesia belum sepenuhnya melatih kemampuan atau keterampilan berbahasa serta belum sepenuhnya meningkatkan daya apresiasi terhadap sastra. Guru belum secara optimal menyediakan ruang memadai untuk siswa dalam memperkaya pengalaman belajar mereka. Selain itu guru juga kurang mengadakan latihan bagi siswa untuk meningkatkan keterampilan menyimak, berbicara, membaca, menulis, dan memirsa. Lebih penting lagi, guru belum sepenuhnya melaksanaan pembelajaran dengan menekankan keterampilan berpikir aras tinggi.

Pembelajaran demikian tentu bertentangan dengan praktik pembelajaran yang sesuai dengan Kurikulum 2013. Pada Kurikulum 2013 ditekankan pentingnya penerapan pendekatan ilmiah (saintifik) dalam pembelajaran. Pendekatan ilmiah diyakini sebagai inti perkembangan dan pengembangan sikap, keterampilan, dan pengetahuan peserta didik. Di dalam pendekatan ilmiah, para ilmuan mengutamakan penalaran induktif (inductive reasoning) daripada penalaran deduktif (deductive reasoning). Untuk diketahui bahwa penalaran deduktif melihat fenomena umum untuk kemudian ditarik simpulan yang spesifik. Sebaliknya, penalaran induktif melihat fenomena spesifik untuk kemudian ditarik simpulan secara umum. Berkaitan dengan sistem penilaian, masih ditemukan beberapa penilaian yang lebih menekankan pada aspek pengetahuan. Apalagi aspek pengetahuan tersebut juga masih pada level mengingat, memahami, dan mengaplikasikan; sebaliknya masih kurang pada aspek menganalisis, mengevaluasi, dan mencipta. Selain itu, aspek keterampilan belum menjangkau ke seluruh peserta didik. 
Metode ilmiah merujuk pada teknik-teknik investigasi atas suatu atau beberapa fenomena, memperoleh pengetahuan baru, atau mengoreksi dan memadukan pengetahuan sebelumnya. Untuk dapat disebut ilmiah, metode pencarian (method of inquiry) harus berbasis pada bukti-bukti dari objek yang dapat diobservasi, empiris, dan terukur dengan prinsip-prinsip penalaran yang spesifik. Karena itu, metode ilmiah umumnya memuat serangkaian aktivitas pengumpulan data melalui observasi atau ekperimen, mengolah informasi atau data, menganalisis, kemudian memformulasi, dan menguji hipotesis (Kemendikbud, 2013).

Bertalian dengan penilaian, masih ditemukan sejumlah penilaian yang masih lebih menekankan pada aspek kognitif. Aspek kognitif pun masih lebih banyak pada level mengingat, memahami, dan mengaplikasikan; dan sebaliknya, aspek menganalisis, mengevaluasi, dan mencipta masih kurang. Penilaian pada aspek keterampilan juga masih kurang dan belum menjangkau ke semua peserta didik.
Kemampuan guru dalam mengembangkan instrumen tes dan nontes membutuhkan tindakan perbaikan (treatment) karena kurangnya pengetahuan dalam mengimplementasikan dimensi HOTS. Penelitian ini memfokuskan HOTS pada dimensi penyelesaian masalah, pemikiran kritis, pemikiran kreatif, reflektif, dan metakognitif. Beberapa langkah dalam mengembangkan instrumen tes, yakni ada 8 langkah yang mesti dilakukan untuk mengembangkan tes hasil belajar atau prestasi belajar, yakni: 1) menyusun spesifikasi tes; 2) menulis soal tes; 3) menelaah soal tes; 4) melakukan ujicoba tes; 5) menganalisis butir soal; 6) memperbaiki tes; 7) merakit tes; 8) melaksanakan tes; 9) menafsirkan hasil tes (Mardapi, 2007: 88). Pengetahuan guru mengenai langkah tersebut diinternalisasi mengenai pengembangan soal berbasis HOTS (higher order thinking skills).

Berikut ini adalah data berupa soal yang dibuat oleh guru sebelum diadakannya tindakan perbaikan (treatment).

Tabel.1 Data Soal yang Dibuat oleh Guru

\begin{tabular}{|l|}
\hline Bacalah teks di bawah ini! \\
$\qquad \begin{array}{l}\text { Kantin-kantin di sekolahku terlihat bersih dan tertata rapi. Semua makanan tertutup } \\
\text { plastik transparan agar terlihat pembeli, tetapi tidak dihinggapi lalat. Aroma khas } \\
\text { makanan menyebar dari sudut-sudut kantin menerbitkan air liur untuk mencicipi. } \\
\text { Rasanya aku ingin menikmati_semua yang ada di semua kantin. }\end{array}$ \\
Sinonim kata yang dicetak tebal adalah ....
\end{tabular}

BASASTRA Jurnal Bahasa, Sastra, dan Pengajarannya

Volume 9 Nomor 1, April 2021, P-ISSN 2302-6405, 2E-ISSN 2714-9765 

A. menyantap
B. memangsa
C. menghabiskan
D. menelan

Instrumen tersebut tidak karena itu, proses berpikir HOTS belum menunjukkan proses kreatif sehingga terukur, termasuk dimensi refleksinya. tanpa membaca secara keseluruhan isi Berikut ini adalah analisis instrumen tes dari teks wacana yang disajikan, peserta pada soal sebelum guru mendapatkan didik dapat menjawab soal. Padanan kata tindakan peningkatan kompetensi yang disajikan dan menemukan padanan paling tepat tidak sesuai dengan kemampuan berpikir pada anak jenjang SMP. sekolah menengah pertama (SMP). Oleh

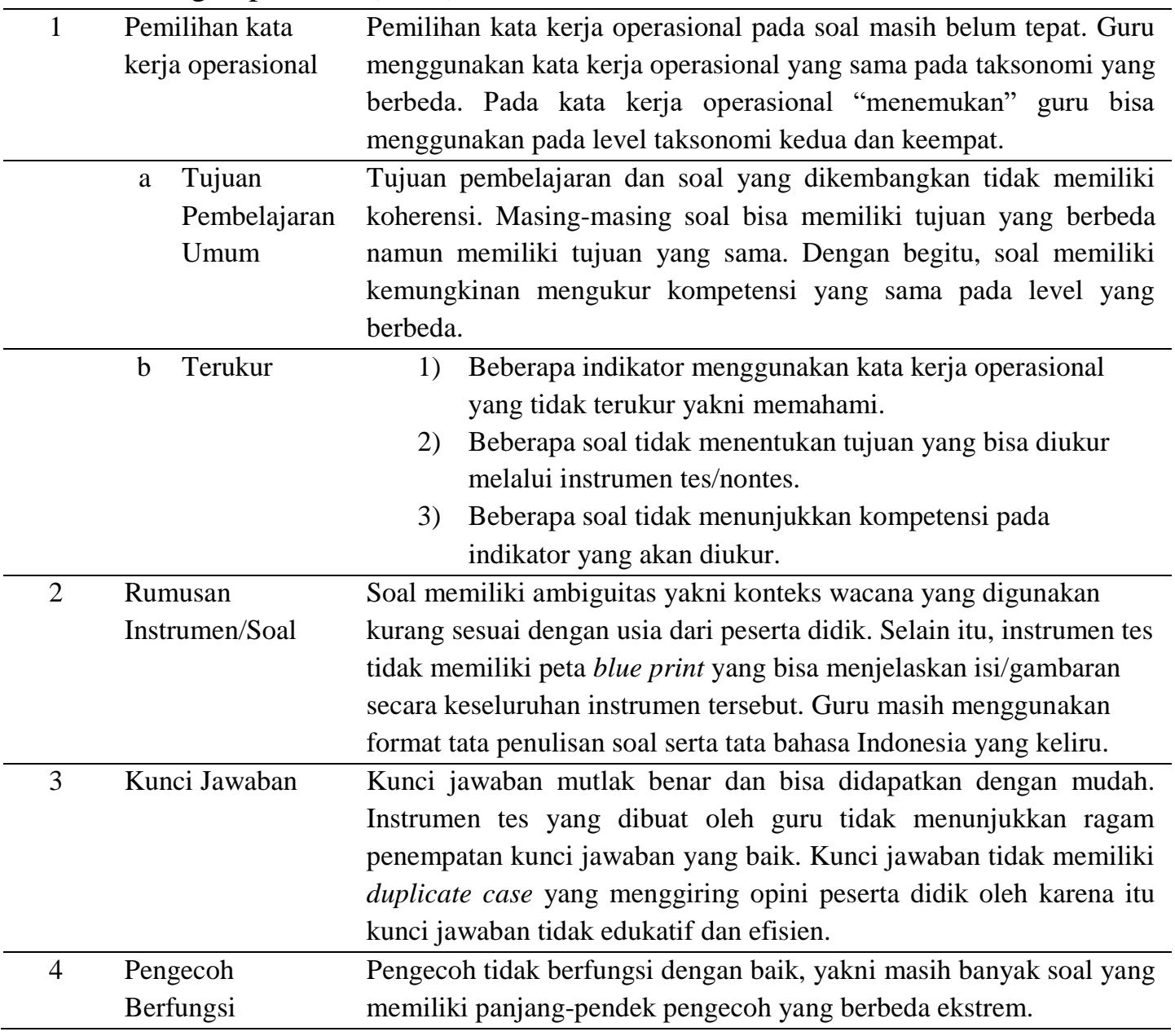




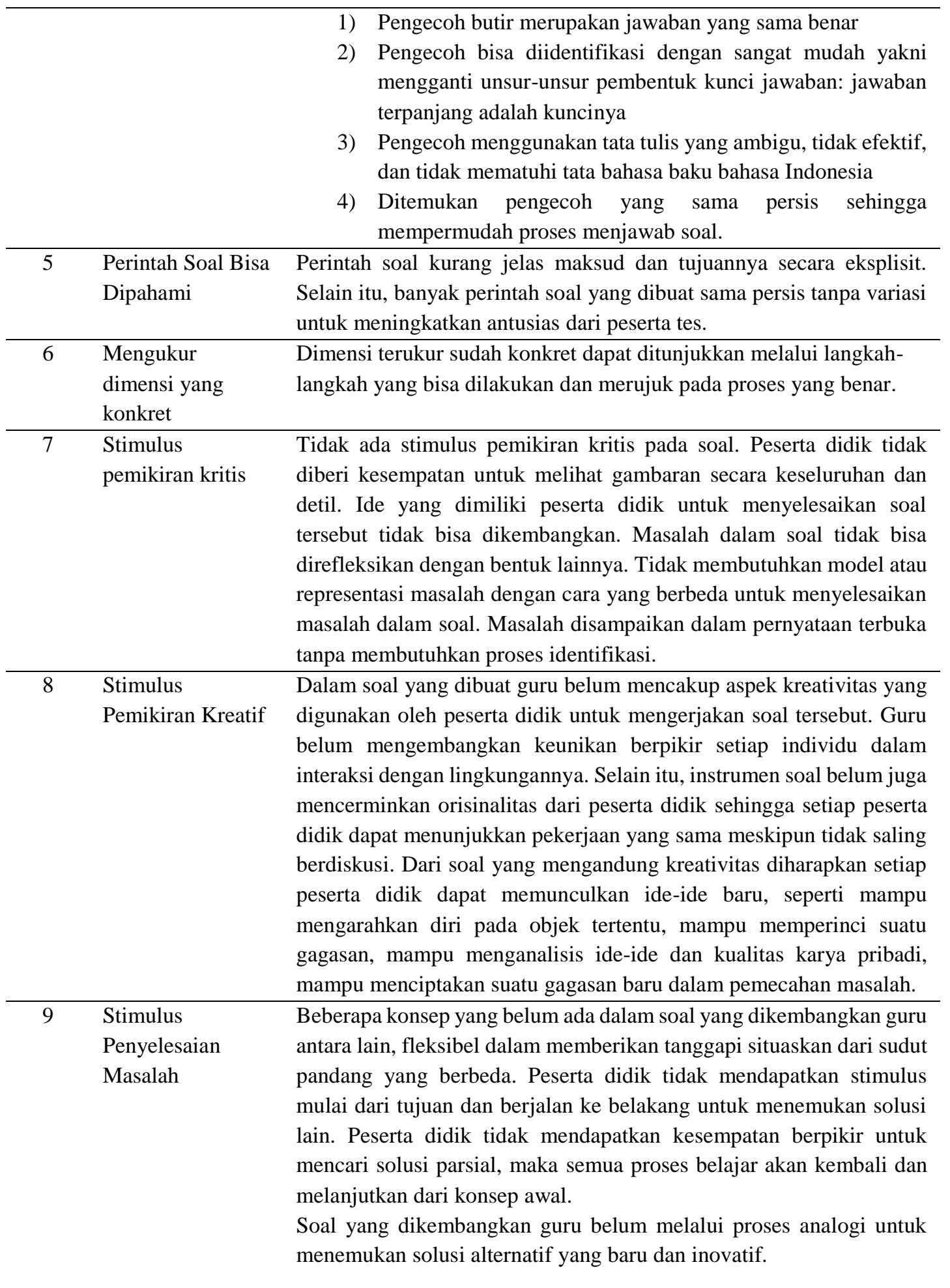

BASASTRA Jurnal Bahasa, Sastra, dan Pengajarannya

Volume 9 Nomor 1, April 2021, P-ISSN 2302-6405, 2E-ISSN 2714-9765 
10 Dimensi Reflektif Proses berpikir relektif meliputi menghafal, mengambil informasi/pengetahuan yang telah direkam sebelumnya. Proses reflektif juga dilanjutkan dalam mengambil apa yang dirasakan sebagai kenyataan dan, tanpa pengetahuan atau bukti, secara tepat dijadikan keputusan akhir. Proses berpikir ditekankan pada pola antara ide-ide abstrak kemudian mengumpulkannya untuk membentuk gambaran yang lengkap. Pada akhirnya, berpikir reflektif menuntut peserta didik untuk mampu menganalisis situasi secara objektif dengan mengumpulkan informasi dari semua sumber yang mungkin, dan kemudian mengevaluasi aspek yang nyata dan tidak berwujud, serta implikasi dari setiap tindakan.

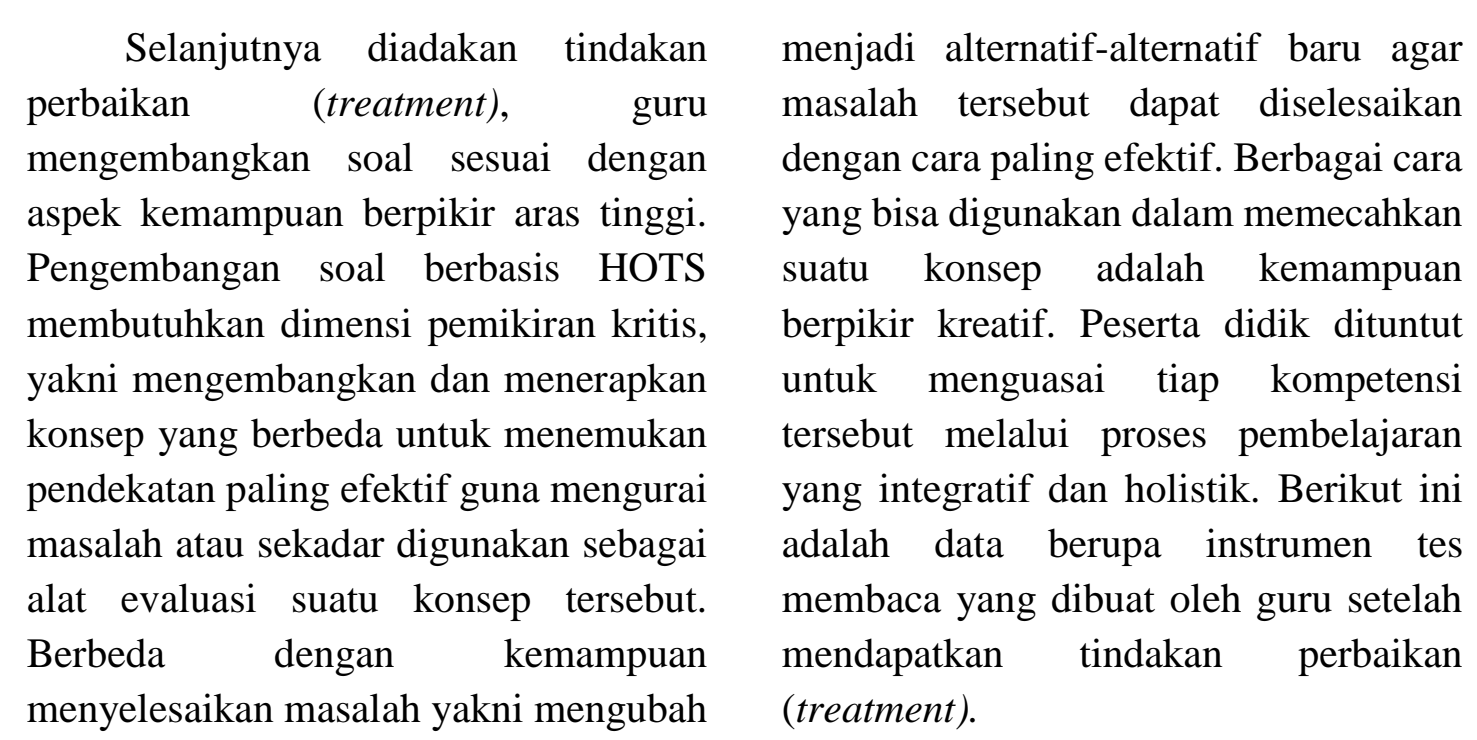
konsep mentah dalam sebuah masalah

Tabel 2. Instrumen Tes Membaca yang Dibuat oleh Guru

\begin{tabular}{|c|c|}
\hline \multicolumn{2}{|c|}{ Cermati teks berikut! } \\
\hline Pewawancara & :"Mengapa kita harus bersikap disiplin?" \\
\hline Narasumber & $\begin{array}{l}\text { : "Kita harus bersikap disiplin. Hal tersebut perlu dilakukan karena sangat } \\
\text { bermanfaat bagi kehidupan kita dan orang lain." }\end{array}$ \\
\hline Pewawancara & : “Contohnya bagaimana, Pak?” \\
\hline Narasumber & $\begin{array}{l}\text { : "Dengan memiliki sikap disiplin segala aktivitas yang kita lakukan akan } \\
\text { berjalan tertib dan lebih teratur. Selain itu, sikap disiplin dapat membuat kita } \\
\text { menjadi pribadi yang kokoh dan taat pada aturan." }\end{array}$ \\
\hline
\end{tabular}

BASASTRA Jurnal Bahasa, Sastra, dan Pengajarannya

Volume 9 Nomor 1, April 2021, P-ISSN 2302-6405, 2E-ISSN 2714-9765 


A. Dengan memiliki sikap disiplin segala aktivitas yang kita lakukan akan berjalan tertib
dan lebih teratur. Selain itu, sikap disiplin dapat membuat kita menjadi pribadi yang
kokoh dan taat pada aturan. Kita harus bersikap disiplin.
B. Kedisiplinan membuat kegiatan belajar mengajar dapat berjalan dengan lancar. Siswa
akan mematuhi peraturan yang berlaku. Selain itu, sikap disiplin dapat membuat kita
menjadi pribadi yang kokoh dan taat pada aturan. Kita harus bersikap disiplin.
C. Dengan memiliki sikap disiplin segala aktivitas yang kita lakukan akan berjalan tertib
dan lebih teratur. Selain itu, sikap disiplin dapat membuat kita menjadi pribadi yang
kokoh dan taat pada aturan. Kedisiplinan juga membuat kegiatan belajar mengajar
dapat berjalan dengan lancar.
Kita harus bersikap disiplin. Hal tersebut perlu dilakukan karena sangat bermanfaat
bagi kehidupan kita dan orang lain. Dengan memiliki sikap disiplin, segala aktivitas
yang kita lakukan akan berjalan tertib dan lebih teratur. Selain itu, sikap disiplin dapat
membuat kita menjadi pribadi yang kokoh dan taat pada aturan

Tabel 3. Indikator Pencapaian

\begin{tabular}{lll}
1 & Pemilihan kata \\
kerja operasional & $\begin{array}{l}\text { Kata kerja dikoreksi dengan baik yakni menggunakan kata kerja } \\
\text { yang bisa dipahami oleh peserta didik pada usia SMP dengan } \\
\text { memperhatikan konteks yang disajikan oleh guru secara umum. }\end{array}$ \\
\hline
\end{tabular}

BASASTRA Jurnal Bahasa, Sastra, dan Pengajarannya

Volume 9 Nomor 1, April 2021, P-ISSN 2302-6405, 2E-ISSN 2714-9765 


\begin{tabular}{|c|c|c|}
\hline & $\begin{array}{l}\text { Tujuan } \\
\text { Pembelajaran } \\
\text { Umum }\end{array}$ & $\begin{array}{l}\text { Tujuan pembelajaran merefleksikan kompetensi dan diturunkan } \\
\text { dalam indikator yang jelas. }\end{array}$ \\
\hline & $\begin{array}{ll}\mathrm{b} & \text { Terukur }\end{array}$ & $\begin{array}{l}\text { Semua indikator menggunakan taksonomi Blooms yang terukur dan } \\
\text { bisa dikerjakan sesuai dengan usia peserta didik (termasuk } \\
\text { pemilihan katanya) }\end{array}$ \\
\hline 2 & $\begin{array}{l}\text { Rumusan } \\
\text { Instrumen/Soal }\end{array}$ & $\begin{array}{l}\text { Instrumen soal disusun dengan baku, tidak ambigu dan mudah } \\
\text { dikerjakan. }\end{array}$ \\
\hline 3 & Kunci Jawaban & $\begin{array}{l}\text { Kunci jawaban bisa ditemukan dan tersebar pada posisi yang } \\
\text { berbeda-beda sesuai dengan pola yang acak. }\end{array}$ \\
\hline 4 & Pengecoh Berfungsi & $\begin{array}{l}\text { Pengecoh berfungsi dengan baik, termasuk peletakan pengecoh dan } \\
\text { panjang-pendeknya juga telah didesain dengan baik. }\end{array}$ \\
\hline 5 & $\begin{array}{l}\text { Perintah Soal Bisa } \\
\text { Dipahami }\end{array}$ & $\begin{array}{l}\text { Perintah soal bisa dipahami dan disusun dengan variasi yang berbeda } \\
\text { meskipun pada tujuan pengerjaan yang sama. }\end{array}$ \\
\hline 6 & $\begin{array}{l}\text { Mengukur dimensi } \\
\text { yang konkret }\end{array}$ & $\begin{array}{l}\text { Dimensi terukur konkret langkah pengerjaan bisa dipahami dan } \\
\text { dilaksanakan dengan baik }\end{array}$ \\
\hline 7 & $\begin{array}{l}\text { Stimulus pemikiran } \\
\text { kritis }\end{array}$ & Pemikiran kritis telah terukur dengan baik \\
\hline 8 & $\begin{array}{l}\text { Stimulus Pemikiran } \\
\text { Kreatif }\end{array}$ & $\begin{array}{l}\text { Pemikiran kreatif belum bisa diukur dengan maksimal karena } \\
\text { jawaban yang disajikan guru masih mutlak benar } 1 \text { nomor dan tidak } \\
\text { ada kemungkinan jawaban lainnya. }\end{array}$ \\
\hline 9 & $\begin{array}{l}\text { Stimulus } \\
\text { Penyelesaian } \\
\text { Masalah }\end{array}$ & $\begin{array}{l}\text { Pemecahan masalah belum bisa ditemukan dengan proporsional. } \\
\text { Guru masih belum menyajikan masalah yang tepat sasaran untuk } \\
\text { dipecahkan siswa melalui pemikrian kompleks. }\end{array}$ \\
\hline 10 & Dimensi Reflektif & $\begin{array}{l}\text { Proses berpikir reflektif telah memberikan kesempatan kepada } \\
\text { peserta didik untuk mampu menganalisis situasi secara objektif } \\
\text { dengan mengumpulkan informasi dari semua sumber yang mungkin, } \\
\text { dan kemudian mengevaluasi aspek yang nyata dan tidak berwujud, } \\
\text { serta implikasi dari setiap tindakan. }\end{array}$ \\
\hline
\end{tabular}

Dari pemaparan data sebelum dan sesudah upaya tindakan (treatment), soal yang dibuat oleh guru pada mulanya tidak menunjukkan proses kreatif sehingga tanpa membaca secara keseluruhan isi dari teks wacana yang disajikan, peserta didik dapat menjawab soal. Padanan kata yang disajikan dan menemukan padanan paling tepat tidak sesuai dengan kemampuan berpikir pada anak jenjang sekolah menengah pertama
(SMP). Oleh karena itu, proses berpikir HOTS belum terukur, termasuk dimensi refleksinya. Padahal berpikir tingkat tinggi merupakan keterampilan yang perlu dimiliki siswa pada era globalisasi agar menjadi generasi muda yang berkualitas. Keterampilan tersebut diperlukan agar pemikiran siswa sejalan dengan perkembangan ilmu pengetahuan dan teknologi sehingga dapat berjalan seimbang tanpa ada kesenjangan. 
Perkembangan ilmu pengetahuan ini menuntut siswa lebih terampil, kritis, kreatif, dan inovatif dalam berpikir (Zainal, dkk., 2018).

Soal yang dibuat oleh guru tersebut masih dalam tingkatan Lower Order Thinking Skill (LOTS). Seperti yang diungkapkan dalam taksonomi Anderson dan Krathwohl (2001) terdapat revisi dalam hal pembedaan level. Revisi tersebut yakni pembagian level kognitif menjadi dua, yaitu: cara berpikir tingkat rendah (lower order thinking) terdapat pada level mengingat (C1), memahami (C2), dan mengaplikasikan (C3), sedangkan cara berpikir HOTS berada pada tingkatan menganalisis (C4), mengevaluasi (C5), serta mencipta (C6). Hal tersebut diperkuat dengan pendapat Costa (1991) yang menyampaikan bahwa dalam HOTS sendiri dibagi menjadi empat golongan, yaitu memecahkan masalah, membuat keputusan, berpikir kritis, dan berpikir kreatif.

Berdasarkan penjelasan tersebut, sejalan dengan pendapat Rustam, Rasdawita, \& Priyanto (2020) guru Bahasa Indonesia disarankan dapat meningkatkan kualitas pemahaman tentang HOTS sehingga mereka dapat mendesain, mewujudkan, dan menerapkan pembelajaran berdasarkan HOTS. Upaya untuk meningkatkan kualitas guru Bahasa Indonesia di antaranya yakni dilakukan treatment.
Tindakan tersebut adalah 1) focus group discussion, 2) pelatihan, 3) penugasan, dan 4) review.

Program tersebut berdasarkan penelitian Maryani \& Martaningsih (2020) dapat meningkatkan pengetahuan dan keterampilan guru untuk mengembangkan instrumen penilaian berbasis HOTS. Berdasarkan penelitian tersebut terdapat rekomendasi yakni supaya metode pelatihan dibuat lebih efektif agar mempermudah peserta dalam memahami materi pelatihan

Perlu diketahui bahwa dalam membuat pertanyaan berkualitas baik harus direncanakan terlebih dahulu Dalam hal ini guru lebih dulu harus berpartisipasi dalam pelatihan untuk mengembangkan kemampuan pedagoginya. Jadi, guru mendapatkan pengetahuan dalam memberikan pertanyaan pada sebuah pembelajaran, selain itu juga mengikuti pelatihanpelatihan agar dapat mengembangkan soal-soal HOTS pada pembelajaran. Tak kalah penting, guru harus mampu mengelola kelas pembelajaran dengan baik agar keterampilan berpikir siswa terus berkembang (Rurisfian, dkk., 2019)

Setelah dilakukan tindakan perbaikan (treatment), kemampuan guru dalam mengembangkan soal Bahasa Indonesia mengalami perubahan terutama dalam menentukan kata kerja operasional yang dibutuhkan agar terukur sesuai dengan dimensi tesnya. 
Peserta didik dilibatkan sebagai pemikiran reflektif untuk melihat masalah yang mungkin disajikan oleh guru. Ide pengembangan instrumen tes yang dikembangkan oleh guru bisa bercabang dan divergen sesuai dengan tujuan tes yang hendak dicapai. Indikator menunjukkan kemampuan terukur sebagai alat untuk mencapai tujuan.

\section{SIMPULAN}

Tindakan perbaikan (treatment) dapat meningkatkan kompetensi menyusun soal berperspektif HOTS di SMP Negeri Surakarta. Tindakan perbaikan tersebut tersebut yakni 1) focus group discussion, 2) pelatihan, 3) penugasan, dan 4) review. Setelah dilakukan tindakan perbaikan, kemampuan guru dalam mengembangkan soal bahasa Indonesia mengalami perubahan terutama dalam menentukan kata kerja operasional yang dibutuhkan agar terukur sesuai dengan dimensi tesnya. Pengguna potensial hasil penelitian dari kegiatan pengabdian ini adalah sekolah dan Dinas Pendidikan Kota Surakarta dalam mengembangkan kompetensi pendidik dan peserta didik.

\section{REFERENSI}

Afandi \& Sajidan. (2017). Stimulasi Keterampilan Tingkat Tinggi. Surakarta: UNS Press.

Anderson, L.W., \& Krathwohl, D.R. (2001). A Taxonomy for Learning,
Teaching, and Asessing: A Revision of Bloom's Taxon omy of Educational Objectives. A Bridged Edition. New York: Addison Wesley Longman, Inc.

Arends, R.I. (2012). Learning to Teach. New York: McGraw-Hill Companies, Inc.

Ariyana, Y., dkk. (2018). Buku Pegangan Pembelajaran Beorientasi pada Keterampilan Berpikir Tingkat Tinggi. Jakarta: Ditjen Guru dan Tenaga Kependidikan Kemendikbud.

Costa, A. L. (1991). Developing Minds: Programs for Teaching Thinking (Rev.Ed). Volume 2. Alexandria: ASCD.

Fisher, A. (2001). Critical Thinking: An Introduction. Cambridge: Cambridge University Press.

Kastawi \& Yuliejantiningsih. (2019). Pengembangan Keprofesian Berkelanjutan Guru untuk Meningkatkan Mutu Pendidikan. Kelola: Jurnal Manajemen Pendidikan, 6 (2), 157-168.

Kemendikbud. (2013). Modul Pelatihan Implementasi Kurikulum 2013 SMA/MA dan SMK/MAK Bahasa Indonesia. Jakarta: Kemendikbud.

Kurniati, dkk. (2016). Kemampuan Berpikir Tingkat Tinggi Siswa SMP di Kabupaten Jember dalam Menyelesaikan Soal Berstandar PISA. Jurnal Penelitian dan Evaluasi Pendidikan, 20 (2), 142155.

Mardapi, D. (2007). Teknik Penyusunan Instrumen Tes dan Non-Tes. Yogyakarta: Mitra Cendekia Press.

BASASTRA Jurnal Bahasa, Sastra, dan Pengajarannya

Volume 9 Nomor 1, April 2021, P-ISSN 2302-6405, 2E-ISSN 2714-9765 
Maryani \& Martaningsih. (2020). Pendampingan Penyusunan Soal Higher Order Thinking Bagi Guru Sekolah Dasar. Jurnal SOLMA, 09 (1), 156-166.

Peraturan Menteri Pendidikan dan Kebudayaan Nomor 21 Tahun 2016 tentang Standar Isi Pendidikan Dasar dan Menengah.

Resnick, L. B. (1987). Education and Learning to Think. Washington, DC: National Scademy Press.

Rurisfian, dkk. (2019). Level Berpikir Pertanyaan Guru pada Pembelajaran Bahasa Indonesia. Bahasa: Jurnal Keilmuan Pendidikan Bahasa dan Sastra Indonesia, 2 (2), 111-119.

Rustam, Rasdawita \& Priyanto. (2020). Hots-Oriented Indonesian Language Learning in Senior High School in Jambi. RETORIKA: Jurnal Bahasa, Sastra, dan Pengajarannya, 13 (2), 225-235.

Sudaryanto, dkk. (2019). MultimediaBased Online Test on Indonesian Language Receptive Skills Development. Journal of Physics: Conference Series. 1339 012120: 1-7.
Sutopo. (2002). Metodologi Penelitian Kualitatif. Surakarta: UNS Press.

Undang-Undang Republik Indonesia Nomor 20 Tahun 2003 tentang Sistem Pendidikan Nasional.

Wardani, E., dkk. (2020). Higher Order Thinking Skills dalam Pembelajaran Bahasa dan Sastra Indonesia di Sekolah Menengah Pertama Kota Madiun. Lingua Didaktika: Jurnal Bahasa dan Pembelajaran Bahasa, 4 (1), 2943.

Widodo, T. \& Kadarwati, S. (2013). Higher Order Thinking Berbasis Pemecahan Masalah untuk Meningkatkan Hasil Belajar Berorientasi Pembentukan Karakter Siswa. Jurnal Cakrawala Pendidikan, (1), 161-171.

Zainal, dkk. (2018). Instrumen Asesmen Berbasis Higher Order Thinking Skills dengan Memanfaatkan Kumpulan Cerpen Filosofi Kopi untuk Kelas X. Jurnal Pendidikan: Teori, Penelitian, dan Pengembangan, 3 (12), 15611571. 